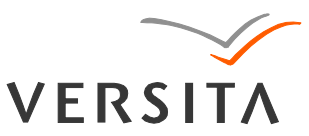

GEOCHRONOMETRIA 39(1) 2012: 30-39

DOI 10.2478/s13386-011-0057-y

VERSITイ

\title{
DENDROCHRONOLOGICAL AND RADIOCARBON DATING OF THE MEDIEVAL STRONGHOLD IN UJŚCIE (POLAND)
}

\author{
MONIKA BOLKA and MAREK KRĄPIEC \\ AGH - University of Science and Technology, Faculty of Geology, Geophysics and Environmental Protection, \\ 30-059 Cracow, Mickiewicza 30, Poland
}

Received 9 May $2011 \quad$ Accepted 2 November 2011

\begin{abstract}
In 2008, the archaeological museum in Piła carried out excavations in the site No. 5 in Ujście upon the river Noteć (Poland), at the Rybacka Street and in the Old Market Square. In 12 archaeological excavations and 4 surveys abundant wooden structures were discovered, from which about 800 samples were taken, mainly of pine (Pinus sylvestris L.) and oakwood (Quercus sp.). The studies were aimed at absolute dating of wood with the dendrochronological method, the wiggle matching fitting curves method, as well as anatomical determination of wood. Absolute dating of the oakwood from the Rybacka Street allowed to distinguish the oldest fortifications of the stronghold from the ninth century, and also intensive introduction of wood in the years 980-1080 AD, whereas analysis of wood from the Old Market (survey IV) allowed to distinguish eight structural levels, from the 1530s until the 970s. On the basis of the pine wood 227-year-long local chronology 2U_02A was produced, dated with the wiggle-matching method for the period 860-1080 $( \pm 10)$ cal. AD. Most of the pine samples proved to represent wood introduced in the $990 \mathrm{~s}$ and $1040 \mathrm{~s}( \pm 10) \mathrm{cal}$. $\mathrm{AD}$, and also some repairs in the years 1000-1030 and 1050-1070 ( \pm 10$)$ cal. AD.
\end{abstract}

Keywords: archaeological wood, dendrological analysis, dendrochronology, radiocarbon dating, Pinus sylvestris L., Quercus sp., Ujście, Poland.

\section{INTRODUCTION}

In 2008, in the site No. 5 in Ujście archaeological excavation studies were carried out that preceded the reconstruction and revitalization of the Old Market Square and the adjacent streets. The excavations resulted in discovering rich wood material, mostly pine (Pinus sylvestris L.) and oakwood (Quercus sp.), representing structural elements of the mediaeval stronghold. This site, dated for the early Middle Ages, had already been excavated before. The first excavation works in Ujście were carried out by L. Leciejewicz and E. Dąbrowski at 9 Rybacka

Corresponding author: M. Krąpiec

e-mail: mkrapiec@agh.edu.pl

ISSN 1897-1695 (online), 1733-8387 (print)

(C) 2011 Silesian University of Technology, Gliwice, Poland.

All rights reserved. street in 1953. The site was identified as remains of an ancient castellan's fortified castle. There were discovered well-preserved structures of the wall, the underlying pier, as well as the settlement buildings (Leciejewicz, 1961). The dendrochronological analysis of three preserved wood samples, made relatively recently, enabled to date the defensive structures for the 970s (time of Prince Mieszko I). Apart from timber structures, other valuable objects were encountered, among others ceramics and spurs dated to the turn of the seventh and eighth and the eighth century (Leciejewicz, 2008).

At establishing the chronology of the archaeological excavation site in Ujście it was decided that, except the commonly applied radiocarbon method, the dendro- 
chronological method should be used as well, successfully practiced in Central Europe for over 20 years (Zielski and Krąpiec, 2004; Danek et al., 2007; Gurskaya, 2007; Rybníček et al., 2010).

Dating oakwood samples from Wielkopolska should not present any substantial problem, since long standard chronology for this area, covering the period 449-1998 $\mathrm{AD}$, has been already constructed (Krąpiec, 1998) and comparative materials from numerous early-mediaeval sites are also accessible (Kara and Krąpiec, 2005). The possibility of dating pine wood looks, however, quite differently. The longest Polish standards produced for the neighbouring areas embrace 1091-2004 AD for Małopolska (Szychowska-Krąpiec, 2010) and the period 11061994 AD for Kujawy and Gdańsk Pomerania (Zielski, 1997). The German standard worked out by Heussner (1996) reaches back from recent to 924 AD. Preliminary estimations, based on archaeological finds, indicated that wood samples from the Ujście pine structures could allow to extend the pine standards hitherto constructed.

\section{STUDY AREA AND MATERIALS}

Ujście is a town situated upon the river Noteć in the north-western part of Poland (Wielkopolska) (Fig. 1). Since 1996 the town of Ujście belongs to the Chapter of the Oldest Towns in Poland. The excavation work carried there in 2008 had rescue character and focused above all on recognizing the settlement zone outside the town walls (Rybacka Street) and the clobber of the stronghold (The Old Market Square). The excavation works were carried out by the District Museum in Piła under the management direction of J. Rola.

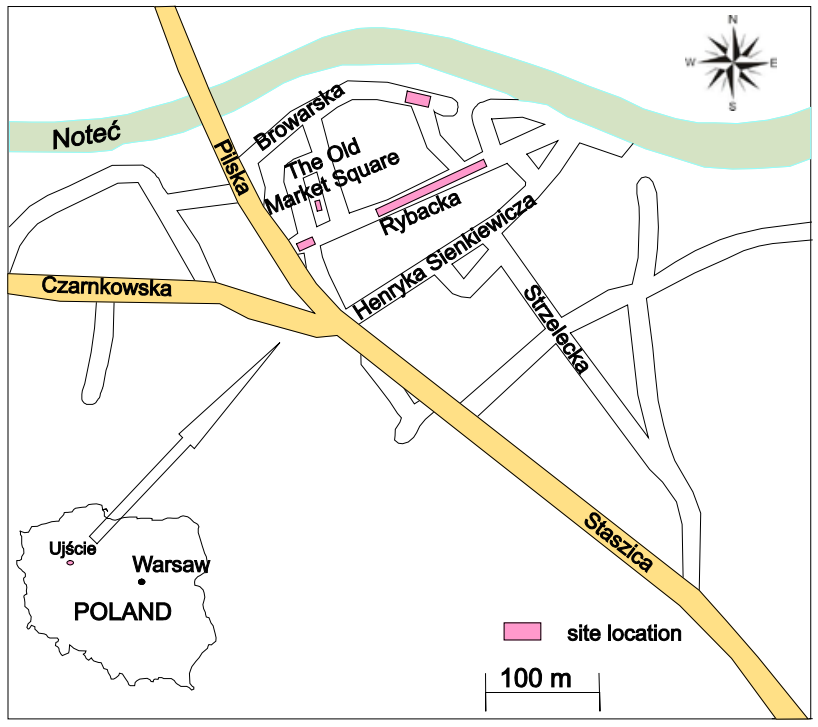

Fig. 1. Location of the archaeological rescue excavations in the Old Town of Ujście.
The first part of timbers (434 samples) was taken from 12 archaeological excavations embracing successive sections of the Rybacka Street $(72.4 \mathrm{~m})$, one of the main streets in Ujście. The next, smaller part of wood (252 samples) was taken from three survey excavations, about $1.5 \times 3 \mathrm{~m}$ in size each, located within the same street. The next investigated site was the Old Market Square, where the fourth survey was established. In this survey, about $2 \times 3 \mathrm{~m}$ in size, well preserved wooden structures from older phases of the early Middle Ages were encountered, up to the depth of over $7 \mathrm{~m}$ below the surface of the terrain. 110 samples of wood were collected in the survey IV.

Altogether, from all excavations about 800 samples of wood were gathered, which represented a broad spectrum of the tree species. These were both structural elements and pales and also trunks of trees, posts, radial planks, boards and branches with traces of processing (Fig. 2). The way of sampling the material for the investigations largely depended on the kind and state of preservation of the building structures and their sizes. In many cases slices (entire circles), up to about $5 \mathrm{~cm}$ in thickness, were taken from trunks with a motor-driven saw. Wood with traces of processing or small twigs were handed over for examinations in the whole or in fragments.

Out of all the wood samples handed over for the dendrochronological analysis, the requirements of the method, i.e. the right number of growth rings and sufficiently good state of preservation of the structure of wood, were fulfilled by 300 samples. Altogether dendrochronological measurements were made for 109 samples of deciduous species (mainly oak) and 191 coniferous samples (predominantly pine).
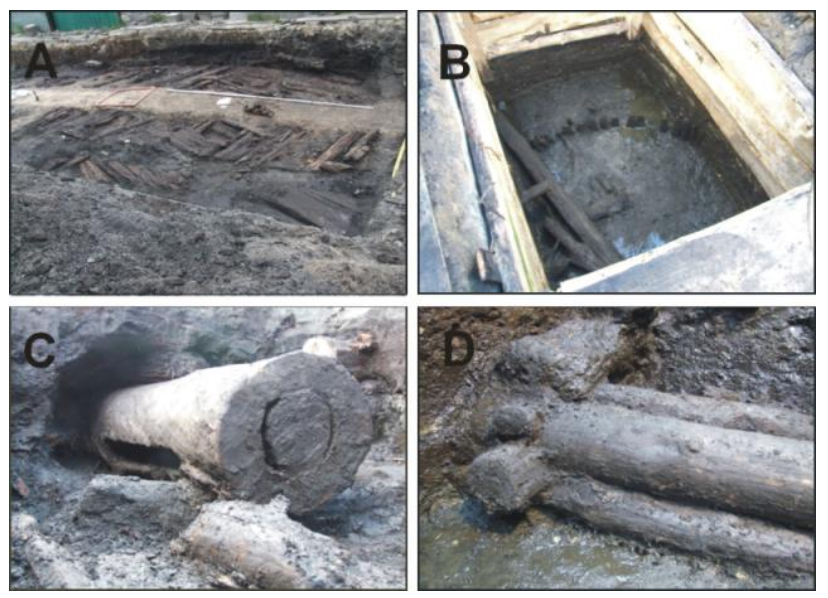

Fig. 2. Samples of wood from building structures and roads: $A-R o a d$ structures preserved, Rybacka Street; $B$ - Oak fence dated to after 1250 AD, IV construction level, survey IV, Old Market Square; C - Beehive dated to 15th c., II construction level, survey IV, Old Market Square; D - Fragment of a building dated to after $1250 A D$, IV construction level, survey IV, Old Market Square. 


\section{METHODS}

\section{Dendrological analysis}

All samples of wood, bigger than a few millimetres and exhibiting at least one annual growth fully developed, were subjected to the anatomical identification. Every sample was subjected to the standard preparation, consisting in cutting the surface layer of wood with a preparation knife. In the case of charred wood samples, legible image of the structure of wood could be obtained through breaking along the perpendicular cross-section plain. Another way of preparation consisted in cutting, with a preparation knife, a relatively thin scrap of wood, allowing for free transmission of light. Such a slice was oriented with respect to the plains and anatomical directions. Determination of wood was made with the stereoscopic microscope, with fluent regulation of magnification from 7 to $90 \mathrm{x}$ and with help of atlases and anatomical keys (Phillips, 1948; Schweingruber, 1990).

\section{Dendrochronological analysis}

Samples of wood complying with the requirements of the dendrochronological method were subjected to standard preparation, consisting in cutting the wood topcoat along the cross section with the preparation knife (OLFA). Measurements of the annual growth widths, with an accuracy of $0.01 \mathrm{~mm}$, were made with help of the DENDROLAB 1.0 apparatus in the Dendrochronological Laboratory AGH-UST in Cracow. The measurement results were recorded with the QUERCUS program (Walanus, 2005). In order to receive representative measurement results, every sample was measured twice, along two different radii. The dendrochronological sequences measured were correlated and averaged which allowed to obtain individual patterns. That was made with the package of programs TREE-RINGS (Krawczyk and Krapiec, 1995). Absolute dating of oaks was made against the Wielkopolska standard (Krąpiec, 1998).

Different procedure was applied at dating pine wood which was connected with the fact that the longest Polish standard reached back only to the beginning of the twelfth century. In the first step of the analysis contemporaneous individual sequences were identified, out of such ones which counted more than 50 annual growth rings. The identification of the contemporaneous individual sequences was based on some statistical parameters, i.e. Pearson's coefficient of linear correlation $r$ and $t$-value (Baillie and Pilcher, 1973) and also on visual matching of the dendrograms. Based on the most convergent sequences the local chronology was produced. Correctness of its construction was tested with the COFECHA program (Holmes, 1999) and then it was compared with available pine standards worked out for Central Europe (Heussner, 1996; Zielski, 1997; Szychowska-Krąpiec, 2010).

\section{Radiocarbon analysis and wiggle-matching method}

Radiocarbon dating presented in this paper was carried out in the Laboratory of Absolute Dating in Skała near Cracow, Poland. The measurements of the ${ }^{14} \mathrm{C}$ concentration were carried out with the scintillation technique (Liquid Scintillation Counter). The measurements were made with the low-background scintillator of new generation, HIDEX 300 SL (Krąpiec and Walanus 2011). Calibration of the radiocarbon dates (expressed as cal. $\mathrm{AD}$ with probability of $68 \%$ and $95 \%$ ) was carried out with help of the program OxCal (3.10 version) (Bronk Ramsey, 2001).

The age of the pine chronology was determined with the wiggle-matching method which allows for dating objects with considerably higher accuracy than in case of single radiocarbon measurements (Pearson, 1986). The analysis was made on six samples containing annual growth rings of the pine trees, relatively dated dendrochronologically (Fig. 3). The curve outlined on the basis of results of the radiocarbon measurements and the time interval between the middles of sections represented by the tree rings was used to determine a curve corresponding to a section of the calibration curve IntCal09 (Reimer et al., 2009). Best fitting of the curve obtained to the calibration curve was determined with help of the OxCal program (3.10 version) (Bronk Ramsey, 2001).

\section{RESULTS}

The anatomical analyses of wood lifted at the archaeological works in Ujście allowed to determine the species changeability represented in the individual culture layers. This changeability, in turn, gives rise to the analysis of preferences at use of all sorts of the tree species in the early-mediaeval stronghold. Altogether 796 samples of wood were subjected to the anatomical investigations. Frequency figures of the individual tree species are presented in Fig. 4. The determination of the tree species demonstrated domination of the conifers (67\%), mainly represented by the pine (Pinus sylvestris L.) - 527 samples. Larch (Larix decidua Mill.) and fir (Abies alba Mill.) were noted only occasionally. Deciduous tree species made up $33 \%$ of the material analysed, with predomination of oak (Quercus sp.) - 17\%, and less frequent alder (Alnus $s p$.) $-7 \%$, and birch (Betula $s p$.) $-4 \%$. The ash tree (Fraxinus excelsior) and willow (Salix sp.) tim-

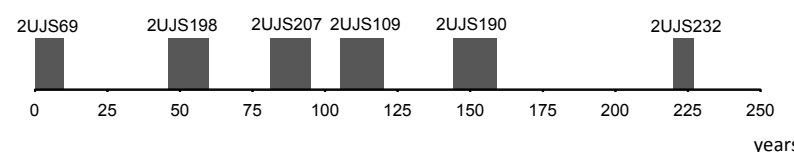

Fig. 3. Samples used for dating with the wiggle-matching method. Growth rings analysed are marked in gray. 


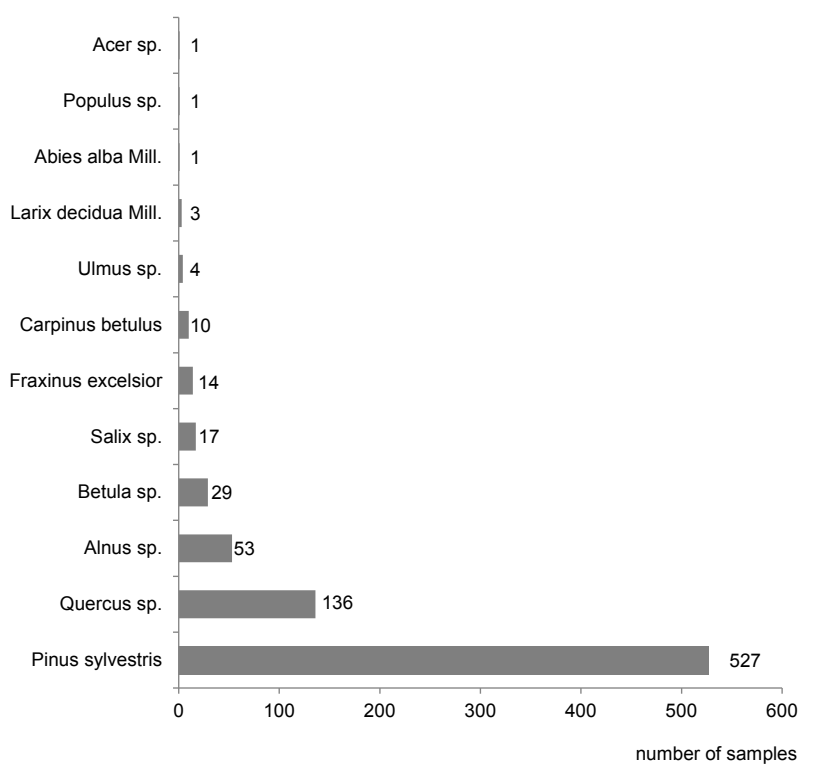

Fig. 4. Anatomical analysis of wood from Ujście.

bers were noted in considerably lower amounts $(2 \%$ each), whereas the hornbeam (Carpinus betulus), elm tree (Ulmus sp.), maple (Acer sp.) and poplar (Populus sp.) only occasionally. The frequency pattern of the individual tree species in the structural elements is also very interesting. Posts (97 samples) were made in majority from oakwood $(40 \%)$ and pine $(20 \%)$. They were also made of alder $(12 \%)$, ash tree $(10 \%)$, willow $(7 \%)$ and birch $(6 \%)$. The hornbeam, maple, and elm were used more rarely. Such choice of timber seems to be intentional, on account of higher durability of the pine, oak and alder in aqueous environment (Krzysik, 1953). Thanks to that, these structures were more resistant to decaying.

Finally, out of such rich material, only $37 \%$ of samples complied with the requirements of the dendrochronological method. The measurements of the annual growth widths were made for 106 samples of the deciduous tree species (96 oaks, five alder trees, three of the ash, and two elm ones). Amongst the coniferous trees, 189 samples of the pine and two samples of larch were measured. Unfortunately, most samples of the coniferous wood could not be dendrochronologically analysed because of too short individual sequences (less than 25 annual growth rings). The measurements of the coniferous timbers were often difficult because of very narrow incremental zones, weak visibility of the boundaries between the successive annual rings, due to young age of plants or provenance from the top part of the trunk, as well as because of missing rings. Short sequences of the annual growths, representing young trees, also predominated among the oak samples. The sequences measured contained from 24 to 187 annual growth rings; 48 samples were absolutely dated against the regional oak standard for Wielkopolska (Krąpiec, 1998).

Results of dating of the oak samples taken from the excavations in the Rybacka Street are presented in Fig. 5, in form of the block-diagram. 26 wood samples were successfully dated with the dendrochronological method. Thanks to presence of the last ring produced by the tree before cutting it down, so-called ring in bark, five samples could be dated with one-year accuracy. For the remaining samples, deprived of the youngest rings, it was not possible to determine the time of cutting down the oak trees so precisely. However, taking into consideration the fact that majority of the analysed samples represented various beams, it may be assumed that the number of lacking growths should not be higher than several ones. The dates of cutting samples with fragmentary sapwood were evaluated with the formula determining the number of the sapwood rings at the oaks growing in the Wielkopolska region: $13(-7 /+8)$ (Krapiec, 1998). In the case of dating the remaining samples the situation was more difficult on account of lacking of the total sapwood layer. In such cases only the earliest possible date of cutting the tree down may be established; obtained by adding to the date of the youngest heartwood ring preserved the equivalent for the years corresponding to the lacking sapwood rings. One should remember, however, about a number of missing heartwood rings, practically impossible to determine.

Distribution pattern of the results (Fig. 5) points out a considerable period of time from which the examined oakwood originates. Oak structural elements from the oldest fortifications of the stronghold appeared in the Rybacka Street in the excavations labelled with numbers

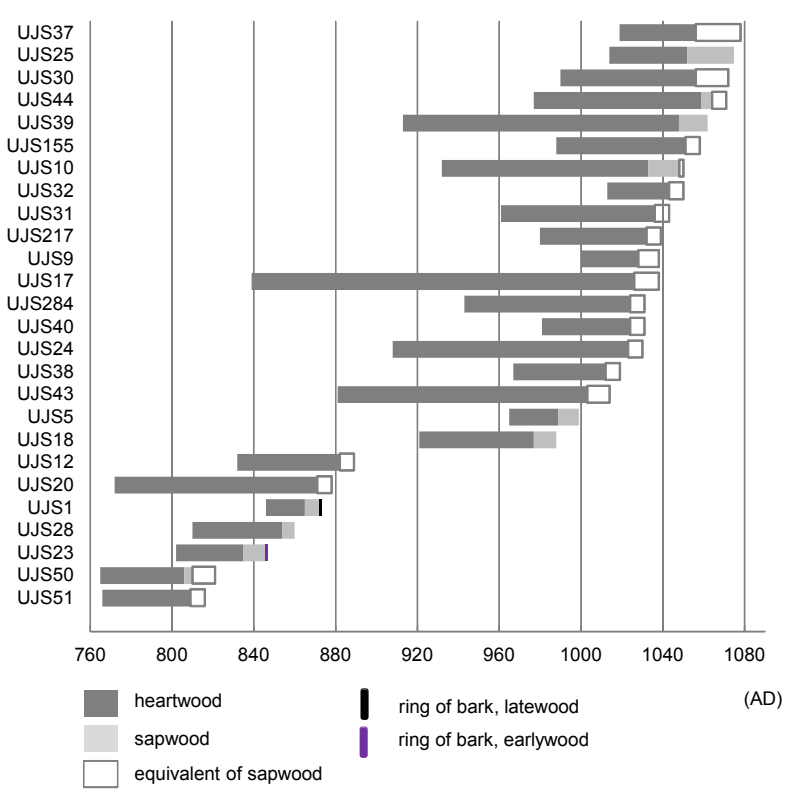

Fig. 5. Dendrochronological dating of growth sequences for oaks from Rybacka Street in Ujście. 
from 171-165 to $110-105$ and in the surveys I-III. They represented trees felled in the period from about $816 \mathrm{AD}$ to about $889 \mathrm{AD}$; the analysed timbers could came from the first stronghold structures in Ujście. The samples with the total sapwood retained allowed for precise determination of their ages. The last ring with the latewood developed in the sample UJS23 pointed at cutting the tree down during the vegetation break, i.e. in the period between late autumn 847 and early spring $848 \mathrm{AD}$, whereas the ring in bark with the earlywood (sample UJS1) allowed to state that oak was cut down in the period from late spring till early summer $873 \mathrm{AD}$.

Apart from the oldest series of samples, numerous oak structural elements represented timbers introduced in the period from $989 \mathrm{AD}$ to $1078 \mathrm{AD}$. The period of more intensive introduction of wood, represented by six samples (UJS24, UJS40, UJS284, UJS17, UJS9, UJS217), took place in the 1030s. The youngest oaks appearing in the excavations at the Rybacka Street came from the trees which ended their growth in the1060s and 1070s; this may point at a next phase of development of the stronghold.

Results of absolute dating of the oak samples explored from the survey IV in the Old Market Square are presented in Table 1 and Fig. 6. Only 22 of 55 oakwood samples handed over for the analysis could be successfully dated, mainly because of low numbers of the tree rings in them. Except for dendrochronological dating, nine radiocarbon dates were produced for samples from different archaeological mechanical layers. Results of the radiocarbon da- ting, presented in Fig. 6 and Table 2 - part A, allowed to distinguish eight structural levels. The first one was outlined by the sample UJS287, dated dendrochronologically to after $1531 \mathrm{AD}$. The second structural level embraced the archaeological mechanical layers V-VII, dated to the fifteenth century. The third level (mechanical layers IX-XIII) was distinguished on the basis of dendrochronological dating of four oak samples (UJS254, UJS252, UJS274, UJS279), dated to the 1340s and 1350s. The fourth level was formed by the mechanical layers XV-XIX, with the highest number of dendrochronologically dated oaks, cut down in the years 1254-1258 AD. Out of that population twelve samples with the ring in bark retained came from the trees cut down in the year $1258 \mathrm{AD}$. Additional radiocarbon analysis was made for one pine sample labelled 2UJS288 (MKL133: 810 \pm 30 BP). The fifth structural level (mechanical layers XXI-XXIII) was dated to the first half of the thirteenth century (sample 2UJS295 - MKL380: $920 \pm 30$ BP). The sixth level (mechanical layers XXV$\mathrm{XLV}$ ) was dated with the radiocarbon method, on the basis of two samples of oak and one of pine (UJS245, UJS246, 2UJS260 - MKL446: 1330 \pm 40 BP, MKL443: 1000 \pm 40 BP, MKL381: 980 \pm 30 BP) and also dendrochronologically (sample UJS275, ca. 1078 AD). The seventh structural level (mechanical layers XLVII-XLIX) corresponds to the period ca. $1040 \mathrm{AD}$ which is indicated by the ${ }^{14} \mathrm{C}$ dating of the pine labelled 2UJS276 (MKL442: $990 \pm 30$ BP). The oldest level, reaching $7 \mathrm{~m}$ below the terrain surface, was dated on the basis of the radiocarbon analysis of pine samples for the years ca. $970 \mathrm{AD}$.

Table 1. Results of dendrochronological analysis of the oakwood samples, archaeological survey IV.

\begin{tabular}{|c|c|c|c|c|c|c|c|c|}
\hline No & Laboratory code & $\begin{array}{l}\text { Mechanical } \\
\text { layer }\end{array}$ & $\begin{array}{l}\text { Sequence } \\
\text { length }\end{array}$ & Sapwood & $\begin{array}{c}\text { Ring of bark (+l-) } \\
\text { Latewood (I) } \\
\text { Earlywood (e) }\end{array}$ & Sequence dating & $\begin{array}{l}\text { Date of cutting } \\
\text { down tree }\end{array}$ & Structural level \\
\hline 1 & UJS287 & 1 & 137 & - & - & $1385-1521$ & after 1531 & 1 \\
\hline 2 & UJS252 & XII-XIII & 47 & $33-47$ &,+ 1 & $1311-1357$ & 1357 & III \\
\hline 3 & UJS254 & XIV-XV & $46+2$ & $31-46$ & - & $1311-1357$ & 1357 & III \\
\hline 4 & UJS274 & $X-X I$ & 44 & $35-44$ &,+ 1 & $1309-1352$ & 1352 & III \\
\hline 5 & UJS279 & X-XI & 33 & $26-33$ &,+ 1 & $1313-1345$ & 1345 & III \\
\hline 6 & UJS239 & XVIII-XIX & 50 & $41-50$ &,+ 1 & $1209-1258$ & 1258 & IV \\
\hline 7 & UJS240 & XVIII-XIX & 39 & $29-39$ &,$+ e$ & $1220-1258$ & 1258 & IV \\
\hline 8 & UJS241 & XVIII-XIX & 60 & $50-60$ &,+ 1 & $1199-1258$ & 1258 & IV \\
\hline 9 & UJS261 & $\mathrm{XVIII-XIX}$ & $43+1$ & $38-43$ & - & $1211-1257$ & 1257 & IV \\
\hline 10 & UJS262 & XVIII-XIX & 52 & $46-52$ & - & $1206-1257$ & 1257 & IV \\
\hline 11 & UJS263 & XVIII-XIX & 58 & $49-58$ & - & $1200-1257$ & 1257 & IV \\
\hline 12 & UJS264 & XVIII-XIX & 52 & $43-52$ &,+ 1 & $1207-1258$ & 1258 & IV \\
\hline 13 & UJS265 & XVIII-XIX & 59 & $49-59$ &,+ 1 & $1200-1258$ & 1258 & IV \\
\hline 14 & UJS266 & XVIII-XIX & 56 & $46-56$ &,+ 1 & $1203-1258$ & 1258 & IV \\
\hline 15 & UJS267 & XVIII-XIX & 58 & $48-58$ &,+ 1 & $1201-1258$ & 1258 & IV \\
\hline 16 & UJS268 & XVIII-XIX & 60 & $49-60$ &,+ 1 & 1199-1258 & 1258 & IV \\
\hline 17 & UJS269 & XVIII-XIX & 52 & $41-52$ &,+ 1 & $1207-1258$ & 1258 & IV \\
\hline 18 & UJS270 & XVIII-XIX & 58 & $50-58$ &,+ 1 & $1201-1258$ & 1258 & IV \\
\hline 19 & UJS271 & XVIII-XIX & 60 & $50-60$ &,+ 1 & 1199-1258 & 1258 & IV \\
\hline 20 & UJS272 & XVIII-XIX & 66 & $55-66$ &,+ 1 & 1193-1258 & 1258 & IV \\
\hline 21 & UJS286 & XVI-XVII & 41 & $32-41$ &,+ 1 & $1214-1254$ & 1254 & IV \\
\hline 22 & UJS275 & $X X X I$ & 171 & $157-171$ & - & $908-1078$ & $1078(-0 /+7)$ & $\mathrm{VI}$ \\
\hline
\end{tabular}


Most of the pine (Pinus sylvestris L.) samples measured represented narrow-ringed trees, and a considerable part of them exhibited complete incremental sequences, with the ring of bark. Correlations of the dendrochronological sequences and visual comparisons of dendrograms allowed to construct the floating chronology 2U_02A, spanning 227 years. It was outlined on the basis of 49 curves characterized with the highest mutual similarity (Fig. 7). The majority of samples from the chronology cover the time interval from 80 to 200 relative year. Only the beginning of the sequence (first 50 years) is poorly defined because it is based on only two sequences; 2UJS69 and 2UJS80. On account of the fact that the pine wood appeared in the excavation together with the oakwood, it may be supposed that it also represented the early-mediaeval period. Unfortunately, hitherto there are no appropriately long dendrochronological curves, reaching so far backwards for the Wielkopolska region. Com-

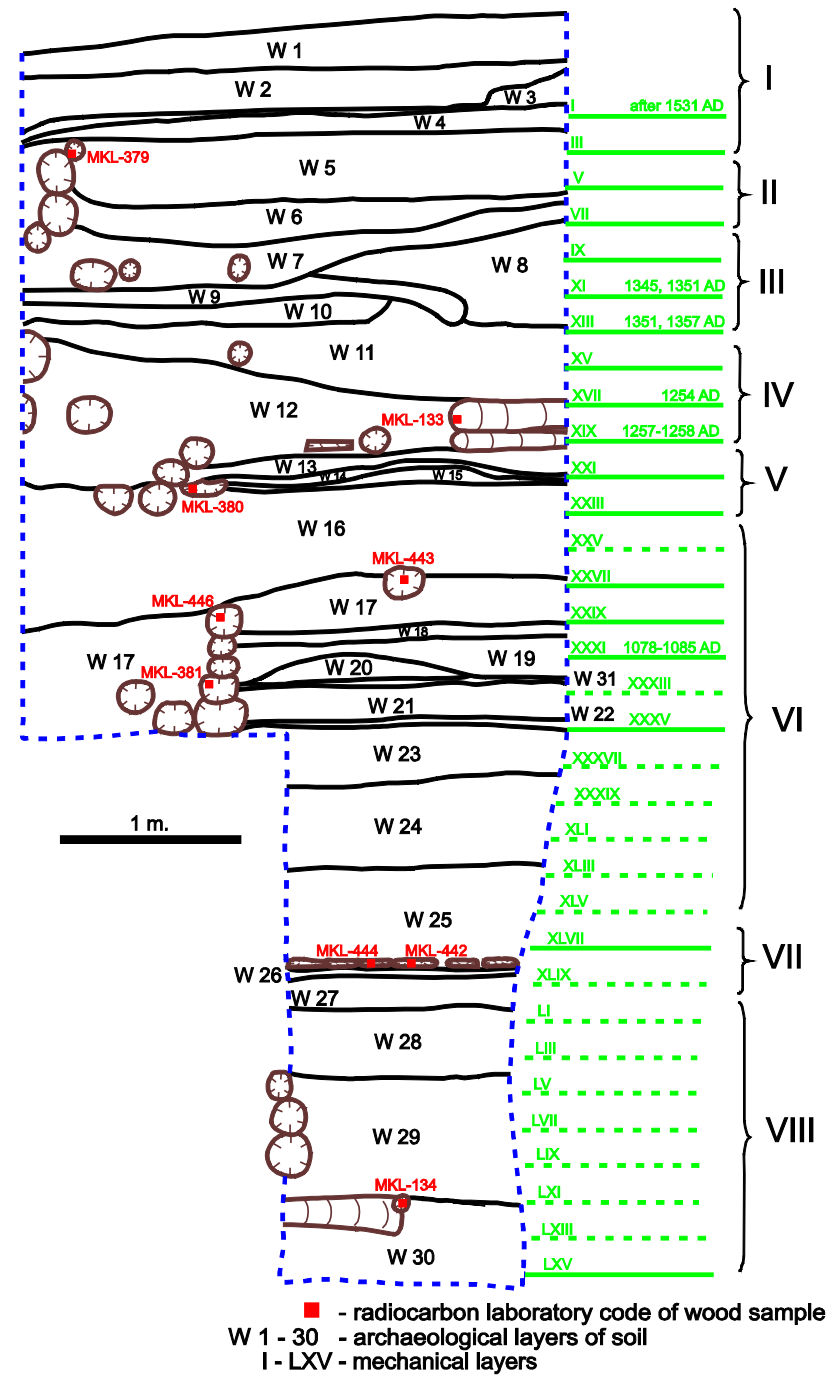

Fig. 6. The Old Market Square in Ujście, archaeological survey IV, profile $W$. parison of the chronology $2 \mathrm{U}$ 02A with the existing pine standards for the neighbouring areas, i.e. the regional chronology for northern Poland, covering the period 1106-1991 AD (Zielski, 1997) and the chronology for northern Germany, 924-1995 AD (Heussner, 1996), did not allow for identification of synchronous positions, most probably because they were too short. In such a situation the wiggle-matching method turned out to be the best one. From the floating chronology 2U_02A six samples were selected, with rings, of which relative dating is presented in Fig. 3 and Table 2 (part B). Fig. 8 presents results of fitting six radiocarbon age determinations of the pine samples with the calibration curve (Reimer et al., 2009). Taking into account position of the first ring dated with the radiocarbon method, from the sample 2UJS61, it is possible to determine the period represented by the curve 2U_02 for the years 860-1080 $( \pm 10)$ cal. AD.

Basing on the chronology dated out, it was possible to establish the age for 102 pine samples (Fig. 9). Among them the elements dated for the first half of the eleventh century predominated. Analysis of the distribution pattern of the age of the pine wood samples used in objects of the stronghold in Ujście permits for distinguishing two phases of intensive introduction of wood. The first structural

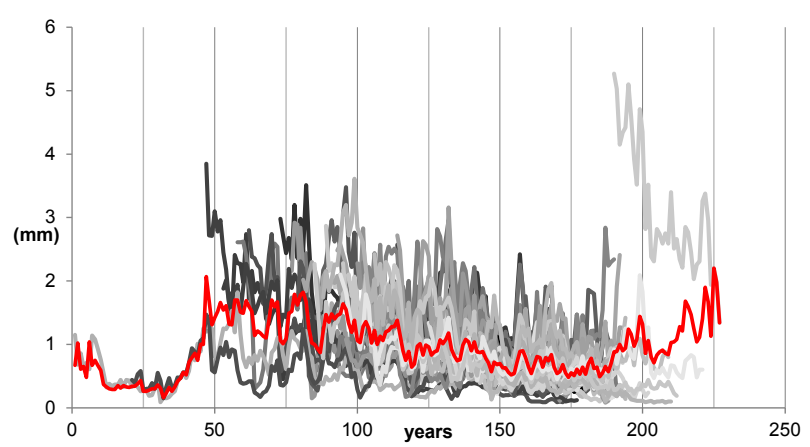

Fig. 7. Dendrochronological dating of growth sequences, forming the local chronology 2U_02A.

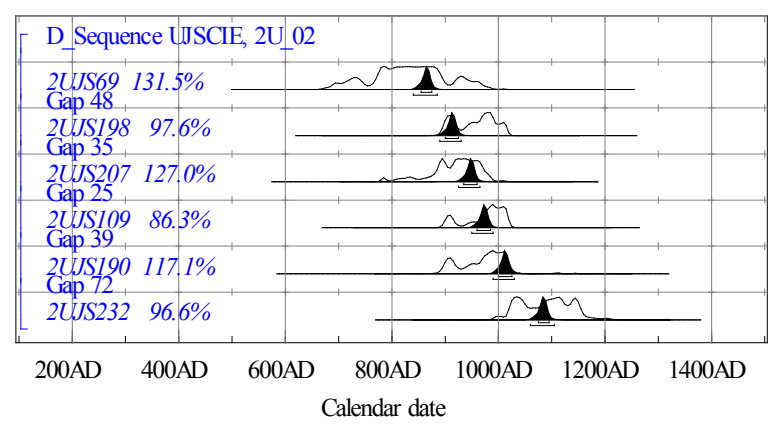

Fig. 8. Wiggle-matching method for the samples forming the chronology 2 U_02A. 


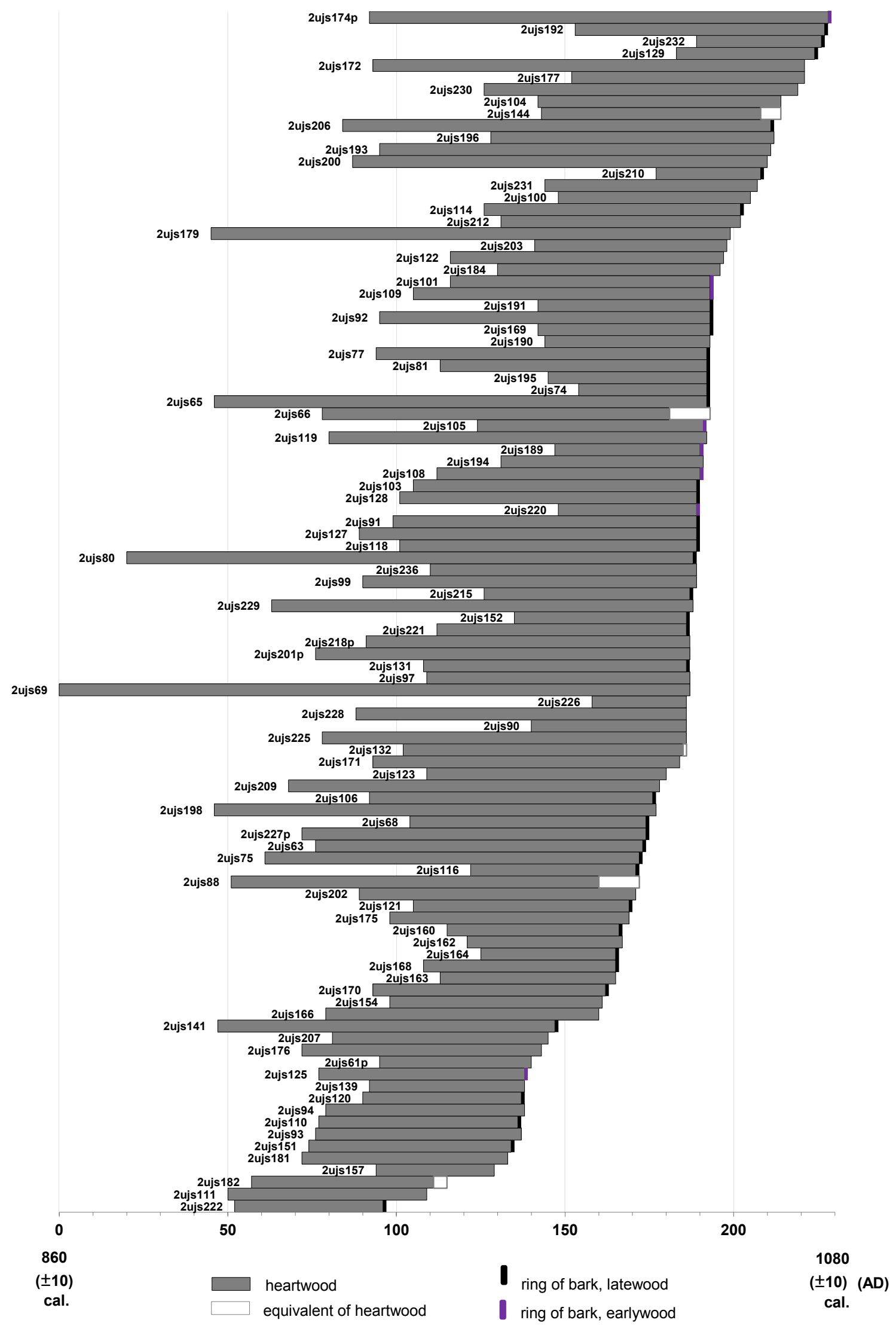

Fig. 9. Correlation diagram of growth sequences sampled in Ujście, forming the pine local chronology 2U_02A. 
Table 2. Sample description with conventional and calibrated ages of wood samples taken from the mediaeval stronghold in Ujście (A - dates of wood connected with an investigation of The Old Market Square in Ujście, B-dates used in order to anchor the floating pine chronology 2U_02A).

\begin{tabular}{|c|c|c|c|c|c|c|c|}
\hline $\begin{array}{c}\text { Sample } \\
\text { description }^{\mathrm{a}}\end{array}$ & $\begin{array}{l}\text { Radiocarbon } \\
\text { laboratory code }\end{array}$ & $\begin{array}{c}{ }^{14} \mathrm{C} \text { age } \\
\text { (BP) }\end{array}$ & $\begin{array}{c}\text { Age range } \\
(68 \%) \\
\text { (cal. AD) }\end{array}$ & $\begin{array}{c}\text { Age range } \\
(95 \%) \\
\text { (cal. AD) }\end{array}$ & $\begin{array}{l}\text { No. of tree- } \\
\text { ring width } \\
\text { series }\end{array}$ & $\begin{array}{l}\text { No. of rings }{ }^{c} / \\
\text { their cross dated } \\
\text { position in tree- } \\
\text { ring chronology }\end{array}$ & $\begin{array}{c}\text { Site descrip- } \\
\text { tion/ } \\
\text { symbol of } \\
\text { mechanical } \\
\text { layer }\end{array}$ \\
\hline \multicolumn{8}{|r|}{ 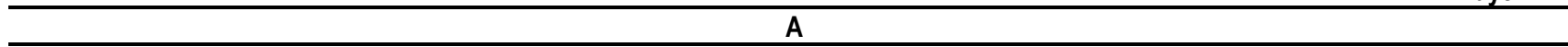 } \\
\hline $\begin{array}{l}\text { 2UJS293, } \\
\text { Pinus syl- } \\
\text { vestris }\end{array}$ & MKL-444 & $1070 \pm 40 \mathrm{BP}$ & $\begin{array}{c}890 \mathrm{AD}-920 \mathrm{AD} \\
(16.0 \%) \\
960 \mathrm{AD}-1020 \mathrm{AD} \\
(52.5 \%) \\
\end{array}$ & $\begin{array}{c}890 \text { AD-1030 AD } \\
(95.4 \%)\end{array}$ & 30 & $25 \mathrm{e}$ & $\begin{array}{l}\text { survey IV I } \\
\text { XLVII }\end{array}$ \\
\hline $\begin{array}{l}\text { 2UJS297, } \\
\text { Pinus syl- } \\
\text { vestris }\end{array}$ & MKL-134 & $1030 \pm 40 \mathrm{BP}$ & $\begin{array}{c}970 \text { AD-1040 AD } \\
(68.2 \%)\end{array}$ & $\begin{array}{c}890 \text { AD-1050 AD } \\
(87.5 \%) \\
1080 \text { AD-1150 AD } \\
(7.9 \%)\end{array}$ & 106 & $20 \mathrm{i}$ & $\begin{array}{l}\text { survey IV I } \\
\text { LX }\end{array}$ \\
\hline $\begin{array}{l}\text { 2UJS276, } \\
\text { Pinus syl- } \\
\text { vestris }\end{array}$ & MKL-442 & $990 \pm 30 \mathrm{BP}$ & $\begin{array}{c}990 \text { AD-1050 AD } \\
(44.1 \%) \\
1090 \text { AD-1120 AD } \\
(19.3 \%) \\
1140 \text { AD-1150 AD } \\
(4.8 \%) \\
\end{array}$ & $\begin{array}{c}980 \mathrm{AD}-1060 \mathrm{AD} \\
(56.8 \%) \\
1070 \mathrm{AD}-1160 \mathrm{AD} \\
(38.6 \%)\end{array}$ & 48 & $15 i$ & $\begin{array}{l}\text { survey IV I } \\
\text { XLVII }\end{array}$ \\
\hline $\begin{array}{l}\text { 2UJS260, } \\
\text { Pinus syl- } \\
\text { vestris }\end{array}$ & MKL-381 & $980 \pm 30 \mathrm{BP}$ & $\begin{array}{c}1010 \text { AD-1050 AD } \\
(36.1 \%) \\
1090 \text { AD-1120AD } \\
(25.4 \%) \\
1130 \text { AD-1150AD } \\
(6.7 \%)\end{array}$ & $\begin{array}{c}990 \text { AD-1160 AD } \\
(95.4 \%)\end{array}$ & 35 & $15 i$ & $\begin{array}{l}\text { survey IV I } \\
\text { XXXV }\end{array}$ \\
\hline $\begin{array}{l}\text { 2UJS246, } \\
\text { Pinus syl- } \\
\text { vestris }\end{array}$ & MKL-443 & $1000 \pm 40 \mathrm{BP}$ & $\begin{array}{c}980 A D-1050 A D \\
(50.5 \%) \\
1090 A D-1120 A D \\
(14.5 \%) \\
1140 A D-1150 A D \\
(3.2 \%)\end{array}$ & $\begin{array}{c}970 \text { AD-1160 AD } \\
(95.4 \%)\end{array}$ & 65 & $15 i$ & $\begin{array}{l}\text { survey IV I } \\
\text { XXVI-XXVII }\end{array}$ \\
\hline $\begin{array}{l}\text { UJS245, } \\
\text { Quercus }\end{array}$ & MKL-446 & $1330 \pm 40 \mathrm{BP}$ & $\begin{array}{c}650 \mathrm{AD}-710 \mathrm{AD} \\
(53.7 \%) \\
740 \mathrm{AD}-770 \mathrm{AD} \\
(14.5 \%)\end{array}$ & $\begin{array}{c}640 \text { AD-780 AD } \\
(95.4 \%)\end{array}$ & 26 & 26 & $\begin{array}{l}\text { survey IV I } \\
\text { XXVIII-XXIX }\end{array}$ \\
\hline $\begin{array}{l}\text { 2UJS295, } \\
\text { Pinus syl- } \\
\text { vestris }\end{array}$ & MKL-380 & $920 \pm 30 \mathrm{BP}$ & $\begin{array}{c}1040 \text { AD-1100 AD } \\
(42.5 \%) \\
1110 \text { AD-1160 AD } \\
(25.7 \%) \\
\end{array}$ & $\begin{array}{c}1020 \text { AD-1100 AD } \\
(95.4 \%)\end{array}$ & 90 & $15 i$ & $\begin{array}{l}\text { survey IV I } \\
\text { XX-XXI }\end{array}$ \\
\hline $\begin{array}{l}\text { 2UJS288, } \\
\text { Pinus syl- } \\
\text { vestris }\end{array}$ & MKL-133 & $810 \pm 30 \mathrm{BP}$ & $\begin{array}{c}1215 \mathrm{AD}-1260 \mathrm{AD} \\
(68.2 \%)\end{array}$ & $\begin{array}{c}1170 \text { AD-1275 AD } \\
(95.4 \%)\end{array}$ & 43 & $12 \mathrm{i}$ & $\begin{array}{l}\text { survey IV I } \\
\text { XVI-XVII }\end{array}$ \\
\hline $\begin{array}{l}\text { 2UJS259, } \\
\text { Pinus syl- } \\
\text { vestris, }\end{array}$ & MKL-379 & $440 \pm 30 \mathrm{BP}$ & $\begin{array}{c}1430 \text { AD-1465 AD } \\
(68.2 \%)\end{array}$ & $\begin{array}{c}1410 \mathrm{AD}-1500 \mathrm{AD} \\
(94.0 \%) \\
1600 \mathrm{AD}-1610 \mathrm{AD} \\
(1.4 \%) \\
\end{array}$ & 106 & $15 \mathrm{e}$ & $\begin{array}{l}\text { survey IV I } \\
\text { II-III }\end{array}$ \\
\hline
\end{tabular}


Table 2. Continuation.

\begin{tabular}{|c|c|c|c|c|c|c|c|}
\hline $\begin{array}{c}\text { Sample } \\
\text { description }\end{array}$ & $\begin{array}{c}\text { Radiocarbon } \\
\text { laboratory code }\end{array}$ & $\begin{array}{c}{ }^{14} \mathrm{C} \text { age } \\
\text { (BP) }\end{array}$ & $\begin{array}{c}\text { Age range } \\
(68 \%) \\
\text { (cal. AD) }\end{array}$ & $\begin{array}{c}\text { Age range } \\
(95 \%) \\
(\text { cal. AD) }\end{array}$ & $\begin{array}{l}\text { No. of tree- } \\
\text { ring width } \\
\text { series }\end{array}$ & $\begin{array}{l}\text { No. of rings } / \\
\text { their cross dated } \\
\text { position in tree- } \\
\text { ring chronology }\end{array}$ & $\begin{array}{c}\text { Site descrip- } \\
\text { tion/ } \\
\text { symbol of } \\
\text { mechanical } \\
\text { layer }\end{array}$ \\
\hline \multicolumn{8}{|c|}{ B } \\
\hline $\begin{array}{l}\text { UJS69, } \\
\text { Pinus syl- } \\
\text { vestris, } \\
\text { w-m }\end{array}$ & MKL-119 & $1190 \pm 50 \mathrm{BP}$ & $\begin{array}{c}770 \mathrm{AD}-900 \mathrm{AD} \\
(64.8 \%) \\
920 \mathrm{AD}-940 \mathrm{AD} \\
(3.4 \%)\end{array}$ & $\begin{array}{c}680 \mathrm{AD}-970 \mathrm{AD} \\
(95.4 \%)\end{array}$ & 187 & $10 \mathrm{i} / 1-10$ & $\begin{array}{c}\text { Rybacka street, } \\
\text { survey I/ } \\
\text { III }\end{array}$ \\
\hline $\begin{array}{l}\text { 2UJS198, } \\
\text { Pinus syl- } \\
\text { vestris, } \\
\text { w-m }\end{array}$ & MKL-123 & $1080 \pm 30 \mathrm{BP}$ & $\begin{array}{c}890 \text { AD-920 AD } \\
(19.9 \%) \\
940 \text { AD-1020 AD } \\
(48.3 \%)\end{array}$ & $\begin{array}{c}890 \text { AD-1020 AD } \\
(95.4 \%)\end{array}$ & 133 & $13 \mathrm{i} / 47-60$ & $\begin{array}{c}\text { Rybacka street, } \\
140-135\end{array}$ \\
\hline $\begin{array}{l}\text { 2UJS207, } \\
\text { Pinus syl- } \\
\text { vestris, } \\
\text { w-m }\end{array}$ & MKL-124 & $1130 \pm 30 \mathrm{BP}$ & $\begin{array}{c}885 \mathrm{AD}-905 \mathrm{AD} \\
(14.6 \%) \\
910 \mathrm{AD}-970 \mathrm{AD} \\
(53.6 \%)\end{array}$ & $\begin{array}{c}780 \mathrm{AD}-790 \mathrm{AD} \\
(1.0 \%) \\
810 \mathrm{AD}-990 \mathrm{AD} \\
(94.4 \%)\end{array}$ & 74 & 14i/82-95 & $\begin{array}{c}\text { Rybacka street, } \\
140-135\end{array}$ \\
\hline $\begin{array}{l}\text { 2UJS109, } \\
\text { Pinus syl- } \\
\text { vestris, } \\
\text { w-m }\end{array}$ & MKL-447 & $1060 \pm 30 \mathrm{BP}$ & $\begin{array}{c}900 \mathrm{AD}-920 \mathrm{AD} \\
(5.4 \%) \\
970 \mathrm{AD}-1020 \mathrm{AD} \\
(62.8 \%)\end{array}$ & $\begin{array}{c}890 \text { AD-1030 AD } \\
(95.4 \%)\end{array}$ & 89 & $15 \mathrm{i} / 106-120$ & $\begin{array}{c}\text { Rybacka street, } \\
\text { survey II / } \\
\text { IV }\end{array}$ \\
\hline $\begin{array}{l}\text { 2UJS190, } \\
\text { Pinus syl- } \\
\text { vestris, } \\
\text { w-m }\end{array}$ & MKL-448 & $1060 \pm 40 \mathrm{BP}$ & $\begin{array}{c}900 A D-920 A D \\
(12.1 \%) \\
960 A D-1020 A D \\
(56.1 \%)\end{array}$ & $\begin{array}{c}890 \text { AD-1030 AD } \\
(95.4 \%)\end{array}$ & 49 & $15 i / 145-159$ & $\begin{array}{c}\text { Rybacka street, } \\
135-130\end{array}$ \\
\hline $\begin{array}{l}\text { 2UJS232, } \\
\text { Pinus syl- } \\
\text { vestris, } \\
\text { w-m }\end{array}$ & MKL-121 & $960 \pm 40 \mathrm{BP}$ & $\begin{array}{c}1020 \mathrm{AD}-1060 \mathrm{AD} \\
(22.2 \%) \\
1080 \mathrm{AD}-1160 \mathrm{AD} \\
(46.0 \%)\end{array}$ & $\begin{array}{c}990 \text { AD-1170 AD } \\
(95.4 \%)\end{array}$ & 38 & $7 e / 221-227$ & $\begin{array}{c}\text { Rybacka street, } \\
145-140\end{array}$ \\
\hline
\end{tabular}

phase took place in the years 990s, whereas the second one in the years 1040s. In the years 1000-1030 and 1050$1070( \pm 10) \mathrm{cal}$. AD the wood was introduced successively, probably at necessary repairs and/or small constructions.

\section{CONCLUSIONS}

1) Dendrochronological analyses enabled to determine the species variability in wood applied in the stronghold in Ujście on the basis of ca. 800 fragments originating from the period from the ninth to the eleventh century in the area of Rybacka Street and from the tenth to the sixteenth century in the survey IV.

2) Oak wooden structures present the oldest phases of the stronghold development, from the beginning of the ninth century to the 1080s. As least two phases of intensive introduction of the pine wood are marked in the 990s and in the 1040s.

3) The chronology $2 U_{-}$02A worked out can serve for dating pine samples from that period from other sites in Wielkopolska.

\section{ACKNOWLEDGEMENTS}

The study was supported by Faculty of Geology, Geophysics and Environmental Protection, AGH - University of Science and Technology in Krakow, as a part of statutory project no 15.11.140.038 and 11.11.140.56, and Absolute Dating Laboratory in Skała, Poland. The research is also a part of PhD thesis of Monika Bolka, M.Sc.Eng., in preparation.

\section{REFERENCES}

Baillie MGL and Pilcher JR, 1973. A simple cross dating program for tree-ring research. Tree-Ring Bulletin 33: 7-14.

Bronk Ramsey C, 2001. Development of the radiocarbon calibration program. Radiocarbon 43(2A): 355-363.

Danek M, Kłusek M and Krąpiec M, 2007. The oak chronology (948$1314 \mathrm{AD}$ ) for the Żary area (SW Poland). Geochronometria 26: 47-52, DOI 10.2478/v10003-007-0006-1.

Gurskaya M, 2007. A 900-years larch chronology for north-western Siberia on the bases of archaeological wood of the Ust-Voykar settlement. Geochronometria 28: 67-72, DOI 10.2478/v10003-007$0028-8$.

Heussner KU, 1996. Zum Stand der Dendrochronologie im unteren Odergebiet. In: Moździoch S, ed, Człowiek a Środowisko w Środkowym i Dolnym Nadodrzu (Man and Environment in the Middle 
and Lower Nadobrze). PAN, Instytut Archeologii i Etnologii, Wrocław, Spotkania Bytomskie 2: 207-211 (in Polish).

Holmes RL, 1999. Users Manual for Program COFECHA. University of Arizona, Tuscon.

Leciejewicz L, 1961. Ujście we Wczesnym Średniowieczu (Ujście in the Early Middle Ages). PAN, Instytut Historii Kultury Materialnej, Zakład Narodowy Imienia Ossolińskich, PWN, WrocławWarszawa-Krakow: 137pp (in Polish).

Leciejewicz L, 2008. Wykopaliska w Ujściu z Perspektywy Półwiecza (Excavations in Ujście from the Perspective of Half-century). In: Gruszka B, ed, ad Oderam fluvium. Ksiegga Dedykowana Pamięci Edwarda Dabrowskiego, Zielona Góra: 83-91(in Polish).

Kara M and Krąpiec M, 2005. Wyniki badań archeodendrochronologicznych wybranych grodzisk wczesnośredniowiecznych z terenu historycznej Wielkopolski, przeprowadzonych w roku 2003 (The results of 2003 archaeo-dendrochronological research of selected early mediaeval fortified settlements in the area of historical Wielkopolska). Fontes Archaeologici Posnanienses 41: 211-232 (in Polish).

Krawczyk A and Krapiec M, 1995. Dendrochronologiczna baza danych (Dendrochronological database). Materiały II Krajowej Konferencji: Komputerowe wspomaganie badań naukowych. Wrocław: 247-252 (in Polish).

Krapiec M, 1998. Oak dendrochronology of the Neoholocene in Poland. Folia Quaternaria 69: 5-134.

Krapiec M and Walanus A, 2011. Application of the triple photomultiplier liquid spectrometer HIDEX $300 \mathrm{SL}$ in radiocarbon dating. Radiocarbon 53(3): 543-550.

Krzysik F, 1953. Nauka o drewnie (Wood science). Wydanie drugie. PWN, Warszawa: 388pp (in Polish).

Pearson GW, 1986. Precise calendrical dating of know growth-period samples using a "curve fitting" technique. Radiocarbon 28: 292299.

Phillips EW, 1948. Identifications of softwoods by their microscopic structure. Forest Product Research Bulletin 22: 1-56.

Reimer PJ, Baillie MGL, Bard E, Bayliss A, Beck JW, Blackwell PG, Bronk Ramsey C, Buck CE, Burr GS, Edwards RL, Friedrich M, Grootes PM, Guilderson TP, Hajdas I, Heaton TJ, Hogg AG, Hughen KA, Kaiser KF, Kromer B, McCormac FG, Manning SW, Reimer RW, Richards DA, Southon JR, Talamo S, Turney CSM, van der Plicht $\mathrm{J}$ and Weyhenmeyer CE, 2009. INTCAL 09 and MARINE09 radiocarbon age calibration curves, 0-50,000 years Cal BP. Radiocarbon 51(4): 1111-1150.

Rybníček M, Koňas P and Kolář T, 2010. The benefits of tree-ring curves detrending for dating archaeological wood. Geochronometria 35: 85-50, DOI 10.2478/v10003-010-0004-6.

Schweingruber FH, 1990. Anatomy of European Woods. An Atlas for the Identification of European Trees, Shrubs and Dwarf Shrubs. Paul Haupt Berne and Stuttgart Publishers, Bern: 800pp.

Szychowska-Krąpiec E, 2010. Long-term chronologies of pine (Pinus sylvestris L.) and fir (Abies alba Mill.) from the Małopolska region and their palaeoclimatic interpretation. Folia Quaternaria 79: 5124.

Walanus A, 2005. Program Quercus. Instrukcja obsługi (Quercus. Users manual). Krakow (in Polish).

Zielski A, 1997. Uwarunkowania Środowiskowe Przyrostów Radialnych Sosny Zwyczajnej (Pinus Sylvestris L.) w Polsce Północnej na Podstawie Wielowiekowej Chronologii (Environmental Conditions of Radial Growth of Pinus sylvestris from North Poland on the Basis of Long Time Chronology). Wydawnictwo UMK, Toruń: $127 \mathrm{pp}$ (in Polish).

Zielski A and Krąpiec M, 2004. Dendrochronologia. PWN, Warszawa. 